
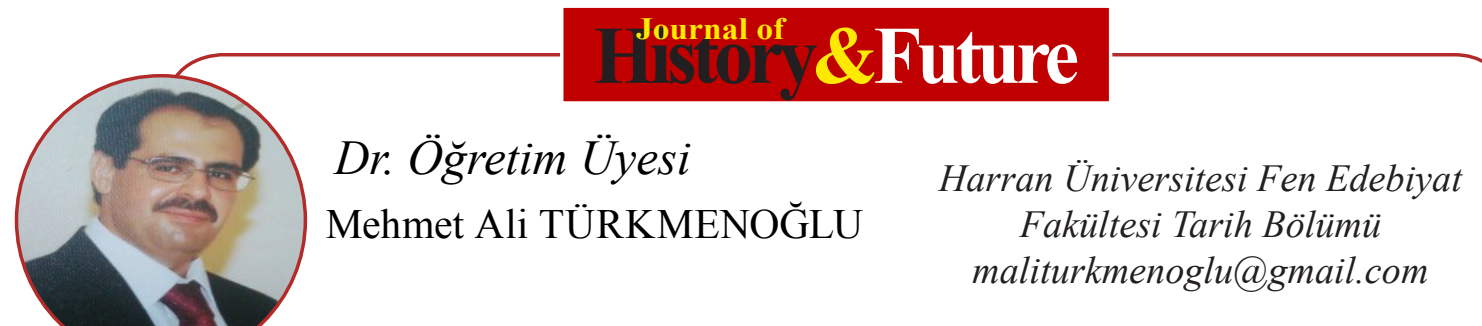

ORCiD: https://orcid.org/0000-0001-8826-6572

Eser Geçmişi / Article Past: 5 A ̆gu 2019/ 8 A ğu 2019

Araştırma Makalesi

DOI: http://dx.doi.org/10.21551/jhf.601640

Research Paper

Orjinal Makale / Orginal Paper

\title{
Osmanlı Devletini Kurtarma Planı: Osmanlıcılık
}

\author{
Ottoman State Rescue Plan: Ottomanism
}

\section{$\ddot{O} z$}

Osmanlı Devleti XIX. Yüzyıla kadar batılı tarzda görülen bir fikri oluşum içine girmemiştir. Batıda Fransız İhtilali’nin çıkmasıyla milliyetçilik akımları özellikle çok uluslu bir devlet olan Osmanlı'da etkisini gösterdi. Osmanlı devlet adamları ve aydınları bu durumdan Osmanlının kurtuluşu için batılı tarzda bir fikrî harekette bulundular. Bu fikir Osmanlıcılık olarak ifade ediliyordu. Bu tespit daha önceki devlet adamları ve padişahlarda Osmanlıcı fikirler olmadığı şeklinde anlaşılmamalı, belki Osmanlı Devleti'nin tebaası olmak sebebiyle aynı milletin ferdi olunması fikrinin Tanzimat'la birlikte sistemleştirdiğini ifade etmektedir.

Osmanlı Devleti'nin dağılmaktan kurtuluşu için dönemin yönetici ve düşünürlerince ortaya atılan ve uygulanan Osmanlıcılık idealinin dayandığı fikrî ve sosyal temeller neydi? Osmanlıcılık fikrinin savunucuları kimlerdi? Osmanlıcılık hareketinin idarî, hukukî, eğitim ve edebiyattaki uygulamaları nasıldı? Bu fikrin Osmanlı toplumunda karşılığı ne oldu? Ya da daha açık bir ifade ile tasavvur edilen Osmanlı milleti niçin var edilemedi ve Osmanlı Devleti'ni kurtaramadı. Bu hedefe ulaşılamayınca bu tasavvurun fikir babaları Osmanlı Devleti'ni kurtarma için hangi yeni ideallere yöneldiler? Bu makalenin amacı bu ve buna benzer birçok soruları cevaplandırmak, Osmanlıcılık fikrinin serüveni hakkında bilgi vermektir.

Anahtar Kelimeler: Tanzimat, Fikir Hareketleri, Osmanlıcılık, , İslamcılık, Türkçülük,

ATIF: TÜRKMENOĞLU Mehmet Ali , "Osmanlı Devletini Kurtarma Planı: Osmanlıc1lı"” Tarih : ve Gelecek Dergisi, 5/2 (Ağustos-2019), s. (408-427)

CITE: TÜRKMENOĞLU Mehmet Ali “Ottoman State Rescue Plan: Ottomanism ” Journal of History and Future, 5/2 (August- 2019), pp. (408-427) 


\begin{abstract}
The Ottoman State did not enter into an intellectual formation that was seen in western style until $19^{\text {th }}$ century. With the outbreak of the French Revolution in the West, the nationalist movements were particularly effective in the Ottoman Empire, which was a multinational state. Ottoman statesmen and intellectuals made a Western-style intellectual movement for the liberation of the Ottomans from this situation. This idea was expressed as Ottomanism. It should not be understood that there were no Ottomanist ideas with the previous statesmen and sultans, but may be, it should be understood that the idea of being a member of the same nation because of being the subjects of the Ottoman state was systemized with Tanzimat.

What were the intellectual and social foundations on which the Ottomanism ideal was based on and applied by the rulers and thinkers of the period for the liberation of the Ottoman? Who were the defenders of the idea of Ottomanism? What were the administrative, legal, educational and literary applications of the Ottomanism movement? What was the response of this idea in the Ottoman State? In other words, why the Ottoman nation could not be created and could not save the Ottoman state. When this goal was not achieved, what new ideals did the fathers of this imagination turn to to save the Ottoman Empire? The aim of this article is to answer these and many other questions and to give information about the adventure of Ottomanism.
\end{abstract}

Keywords: Tanzimat, Intellectual Movements,Ottomanism, Islamism, Turkism

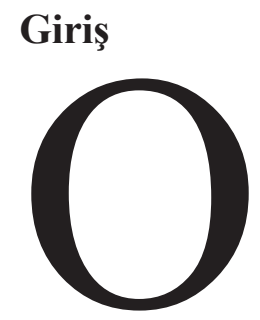

smanlı Devleti'nde kurulduğu günden beri önemli fikir hareketleri yaşanmıştır. Ancak XIX. yüzyıla kadar ortaya atılan fikirler, Batılı anlamda fikir hareketleri olmayıp daha çok dini temele dayalı çeşitli mezhep ve tarikatların savunuculuğunu yapan düşüncelerdir. Bunların müntesipleri çeşitli alanlarda bir üstünlük mücadelesi içinde olmuşlardır. Yani bu fikirler sadece fikrî temele dayalı görüş, düşünce ve inanış farklılıklarından kaynaklanmıyor, bundan başka birçok ekonomik, siyasi ve sosyal sebebe dayanıyordu. Bunlara Bektaşi-Mevlevi ve Alevi-Sünni çekişmeleri örnek verilebilir.

XVIII. yüzyıldan itibaren ise Osmanlı Devleti'nin Batıya karşı gittikçe artan bir şekilde gerilemeye başlaması dönemin devlet adamları ve aydınlarını bunun nedenleri konusunda düşünmeye yöneltti. Düşünceler ve sorunlara bulunan çözümler çeşitli noktalarda odaklaştı. Sorunlara karş1 hemen hemen aynı çözümleri savunanlar daha sonraki araştırmacılar tarafından aynı fikrî akımının savunucusu kabul edildiler. Bunun yanında fikirlerin içindeki çeşitli fraksiyon farklılıkları ise 1lımlılar-radikaller gibi tasniflerle birbirinden ayırt edilmeye çalışıldı.

Osmanlı Devleti'ndeki fikir yapılanması ile ilgili olan bu tasniften sonra XIX. yüzyılın temel problemlerine temas edebiliriz. Bunlar; neden geriliyoruz? Devleti içine düştüğü durumdan nasıl kurtarabiliriz? gibi sorular olmuştur. Bu sorulara getirilen çözüm önerilerinden biri Osmanlıcılık idi. Bu fikri, özellikle Fransız İhtilali sonrasında güçlenen ve devletin varlığını tehdit eden milliyetçilik akımları üzerine devletin dağılmasını önlemek için devlet ve toplum yapısında bütün etnik ve dini ayrılıkları aşan bir ortak kimlik oluşturma düşünce ve hareketi olarak tanımlayabiliriz. ${ }^{1}$ Bunu için izlenmesi gereken yol ise padişahın gözetimi altında yaşayan milletlerin, din ve 1rk

1 Ayrıntılı bilgi için bakınız: Azmi Özcan, "Osmanlıcılık", Türkiye Diyanet Vakfı İslam Ansiklopedisi, TDV. Yayınları Cilt: 33, İstanbul, 2007, s. 485-487. 
farkına göre ayrılmaksızın idarî, dinî, hukukî ve siyasî haklardan eşit faydalanması olarak tanımlandı. Dönemin etkili mütefekkirlerinden Yusuf Akçura, Üç Tarzı Siyaset adlı eserinde Osmanlı ülkesinde Batı örnekliğinde belli başlı üç siyasi yol takip edildiğinden bahseder. Ona göre birinci yol Osmanlı ülkesine tabi farklı milletlerin aynı çatı altında temsil edilmesi yoluyla birleştirerek bir Osmanlı milleti oluşturmak. İkinci yol hilafet hakkının Osmanlı hükümdarlarında olmasından faydalanarak bütün Müslümanları Osmanlı hükümetinin idaresinde birleştirmek ${ }^{2}$ üçüncüsü ise rrka dayanan siyasi bir Türk milleti teşkil eylemekten ibarettir. ${ }^{3}$

\section{Osmanlıcılığın Dayandığı Fikrî ve Sosyal Temeller}

\section{1. Çeşitli Akımların Karşıtlığına Dayalı Osmanlıcılık}

\subsubsection{Batı Karşıtlığına Dayalı Osmanlıcılık}

Batıcılık kısaca Batı Avrupa'nın fikri ve içtimai bileşimini erişilmesi gereken nihai hedef olarak gören bir düşüncedir. ${ }^{4}$ Bu anlayış doğrultusunda yapılan Batı'ya dönük yenilikler toplumun çeşitli kesimlerinden tepki görecektir. Bu tepkiler XVIII. yüzyıl başlarında daha çok isyan hareketleri şeklinde ifade edilmişken, ${ }^{5}$ XIX. yüzyılın sonlarına doğru Batıcılığın bir düşünce akımı olarak da ortaya çıkmasıyla birlikte Batıcılığa karşı düşünce planında da muhalefet hareketleri görülmeye başlamıştır. İşte Osmanlıcılık ve İslamcılık gibi düşünce akımları bu çerçeve içinde de değerlendirilebilir.

\subsubsection{Milliyetçilik Akımlarının Karşıtlığına Dayalı Osmanlıcılık}

Milliyetçilik duygusu, Balkanlarda Osmanlı egemenliğinin başından beri kültür düzeyinde var olan ancak Fransız ihtilalinin yaydığı milliyetçilik akımlarıyla ve Avrupa Devletleri ile Rusya gibi yabancı devletlerin kışkırtmaları sonucu ilk önce Balkan ulusları arasında bağımsızlık gibi amaçlar doğrultusunda gelişen bir duygudur. ${ }^{6} \mathrm{Bu}$ durum Osmanlı Devleti'nde bölünme korkusunu artırmış ve Osmanlı aydınları da karşı tepkilerini birleştirici fikirler öne sürmek şeklinde ortaya koymuşlardır. Osmanlıcılık da bu çerçevede değerlendirilebilecek ideolojilerdendir. Burada birleşme çatısı olarak Osmanlıcılığın seçilmesinin ise iki sebebi vardır: Birincisi imparatorlukta çeşitli milletlerden gelmesine rağmen resmî İslam'a ve kozmopolit başkent kültürüne mensup yani bir Osmanlı tipi diye bilinen özelliklere sahip bir yönetici grup vardı. İște Osmanlıcılığın hedefi var olan tehlike karşısında bir grup yönetici elite mahsus olan bu kimliğin sun’i bir şekilde çeşitli milletleri birleştirme ve bir Osmanlı milleti meydana getirilmesi için kullanılması idi.' İkincisi ise Osmanlı Devleti'nde herkes kendi kültürüne sahip olmakla birlikle "Osmanlı Devleti'nin te-

2 Akçura eserinde bu ifadeyi Frenklerin "Panislamizme" dedikleri şeklinde kayıt düşerek tanımlamıştır. Ayrıntı için bk. Yusuf Akçura, Üç Tarz-ı Siyaset, Ankara, TTK Yayınevi. 1976, s. 19.

3 Akçura, 19.

4 Şerif Mardin, Türk Modernleşmesi, İstanbul, İletişim Yayınları, 4. Baskı, 1994, s. 9.

5 Bu tepkiler ilk defa Kuleli Vakası (1859) diye bilinen ve eski isyan hareketlerini andıran bir olayla somut ifadesini bulmuştur. Ancak Vakanın hangi görüşü savunanların ortaya koyduğu bir tepki olduğu tartışmalıdır. Bu konuda müstakil eser yayınlayan Uluğ İğdemir hareketi Hristiyanlar lehine yapılan islaa hatı hazmedemeyenlerin ve Abdülmecit'in israfından hoşnut olmayanların onun şahsını hedef alarak yaptığı bir hareket olarak ifade etmektedir. Ayrıntı için bakınız: Uluğ İğdemir, Kuleli Vakası Hakkında Bir Araştırma, Ankara, Türk Tarih Kurumu Yayınları, 2009.

6 İlber Ortaylı, İmparatorluğun En Uzun Yüzyılı, (İstanbul, Hil Yayınları, 1983), 38.

7 Ortayl1, 39. 
baasındanım" diyebiliyordu. İşte Osmanlılık fikri ile ortak olan bu aynı devletin tebaasından olma durumu geliştirilerek yükselen milliyetçilik duygularına mukabil aynı devletin tebaası olmak dolayısıyla aynı milletin ferdi olmak fikri oluşturulmaya çalışılmıştı. ${ }^{8}$ Kanun-i Esasi'nin Birinci Maddesinde bu durum şöyle ifade edilmekteydi: "Devlet-i Osmâniyye memalik ve kıta'ât-ı hâzırayı ve eyalât-ı mümtâzeyi muhtevi ve yekvücûd olmağla, hiçbir zamanda ve hiçbir sebeple tefrîk kabûl etmez." Yine 8. Madde "Devlet-i Osmâniyye tâbiiyetinde buluna efrâdın cümlesine herhangi din ve mezhebden olur ise olsun bilâ-istisna Osmanlı tâbir olunur ve Osmanlı sıfatı kanûnen muayyen olan ahvâle göre istihsâl ve izâ'a edilir". ${ }^{9}$ Diğer taraftan toplumda birleştirici bir ideoloji ortaya konulurken ortaya konulan değerin herkesi kapsaması gerekiyordu ve Osmanlı toplumunda herkesi kucaklayabilecek bir tek değer vardı: Osmanlı İmparatorluğuna tebaa olmak. Bunun için ortak kimlik olarak Osmanlılık seçilmişti.

\subsection{Toplumsal Hedeflere Dayalı Osmanlıcılık}

\subsection{Eşit Haklara Dayalı Osmanlıcılık}

XIX. yy. boyunca Osmanlı Devleti'nin Avrupa'ya karşı mücadelelerinde başarısız olması ve Avrupa devletlerinin her mücadelede azınlıkları isyana teşvik etmesi Osmanlı devlet adamlarında Batı Avrupa Devletleri'nin Osmanlı Devleti lehine dönmesini sağlamak suretiyle bu azınlıklar meselesinden kurtulabilineceği fikrini uyandırd1. Fransa bunun Osmanlı Devleti'nin gayrimüslim tebaasına hukuki alanda eşit haklar verilmesi yoluyla olabileceğini öğütledi. I. Mahmut da bunu kabul etti ve çeşitli fermanlarında bu yönde mesajlar verdi. ${ }^{10}$ Böylece bir Osmanlı milleti inancı oluşturulması ve bağımsız birer millet olma yolunda gün geçtikçe adımlar atan azınlıklara alternatif olarak sunulmasının dayanaklarından birisi, her milletin eşit haklara sahip olduğu ilkesi ortaya konuluyordu. Bu ilkenin ilk somut uygulamalarını Tanzimat Fermanında görülmektedir. Daha sonraki yıllarda ve Avrupa devletlerinin desteğine fevkalade ihtiyaç duyulduğu bir zamanda (Kırım Savaşı 1854-56) Avrupa devletlerinin baskısıyla ilan edilen Islahat Fermanında da bu haklar hem teyit hem genişletilmekle beraber gayrimüslim milletlere sadece yeni imtiyazlar verilmemiş askerlik gibi Müslümanlara özgü yeni sorumluluklar da getirilmiştir. ${ }^{11}$

Osmanlıcılığı eşit haklara dayalı olarak gerçekleştirmek için Meşrutiyet döneminde de adımlar atıldı. Bu konuda Kanun-i Esasi'nin metninde de dikkat çekici tanımlamalar vardır. Mesela 17. Madde "Osmanlıların kâffesi huzur-u kanûnda ve ahvâl-i dîniyye ve mezhebiyeden mâadâ memleketin hukuk ve vezâifinde mütesâvidir" demektedir. ${ }^{12}$

8 Enver Ziya Karal, Osmanlı Tarihi, (Ankara, TTK yayınları, 4. Baskı, 1973), c. 7, 297.

9 Düstur, 1. Tertip, c. 4, s.4-5.

10 Buna işaret eden bir ifadesi olarak “Ben tebaamın Müslüman'ını camide, Hristiyan'ını kilisede, Musevi’sini havrada fark ederim. Aralarında başka fark yoktur cümlesi hakkında adalet ve muhabbetim kavidir ve hepsi has evladımdır." Özcan, 485.

11 Burada bütün Müslümanlar için bir millet gayrimüslimler için ise milletler tabirini kullanmasının sebebi Osmanlı literatüründe bütün Müslümanların tek bir millet gayrimüslimlerin ise Rum Milleti, Ermeni Milleti diye ayrı ayrı milletler olarak ifade edilmiş olmalarıdır. Osmanlı Devleti’nde toplumsal yapı "millet sistemi" üzerine inşa edilmişti. Sosyal yapıdaki "millet" kelimesinin manası ise bugünkü anlamından oldukça farklıdır. Millet; "din, mezhep" ve "şeriat" anlamında kullanılmaktaydı. Kısacası gayrimüslimlerin sosyal ve siyasî konumu mensup oldukları din anlayışına göre sınıflandırıldı ve her bir din ayrı millet olarak kabul gördü. Sosyal ve siyasî yapı tamamen işte bu millet sistemine göre belirlendi. Şerif DEMİR, “Tanzimat Döneminde Bir Devlet Politikası Olarak Osmanlıcılık”, Selçuk Üniversitesi Türkiyat Araştırmaları Dergisi, S. 29, 2011, s. 334.

Düstur, 6. 


\subsubsection{Meșrutiyete Dayalı Osmanlıcılık}

Osmanlılık emelinin gerçekleşmesi için meşrutiyete dayandırılması gerektiği fikrini ilk defa Yeni Osmanlılar ortaya atmıştır. Onlara göre İmparatorluğunu oluşturan çeşitli milletler oluşturulacak bir meclis vasıtasıyla yönetime katılabilecekler böylece de mukadderatını yönlendirdikleri devlete sahip çıkacaklar bu da Osmanlılık şuurunun doğmasını kolaylaştıracaktı. Burada dikkat çekici bir nokta da meclise karşı olanlarda Osmanlı birliğinin devam ettirilmesi gerekçesiyle meclise karşı çıkıyorlard1. Onlara göre oluşacak bir meclis birlikten çok ayrılığa neden olacaktı. Çünkü her temsilci kendi mensup olduğu ayrılığı temsil edecek kimse kendi menfaatini başkasına feda etmeyeceğinden bu durum da çekişmeleri artıracaktı. Onlara göre Meşrutiyet yönetimi tek milletli devletler için uygun olabilirdi. Ancak Osmanlı Devleti gibi çok uluslu devletler ancak merkeziyetçi mutlak yönetimlerle bir arada idare edilebilirdi. Nitekim meşrutiyet karşıtlarının bir savunması da meşrutiyetçilerin örnek aldığı İngiltere'nin de Hindistan'daki milyonlarca Müslüman tebaasından bir tek mebus almamasıydı.

Bütün bu söylenilenlerden Osmanlılık idealinin Batı'ya, Batı kaynaklı bazı akımların karşıtlığına ve oluşturulmak istenen bazı ideallere dayandırıldığını bir toprak bilinci, bir ulus bilinci, bir ulusal ekonomi gibi toplumsal dayanaklardan yoksun, Avrupa'nın desteği olmadan ayakta duramayacak bir egemenlik arzusu olduğu çıkarılabilir. ${ }^{13}$ Avrupa ise bu ideolojide amaçlanan birliğin gerçekleşmesi için destek değil engel olmuştur.

\subsection{Osmancılık Fikrinin Ortaya Çıkışı}

Osmanlılık fikrinin doğuşunda en etkin sebep etnik temele dayalı milliyetçilik akımlarının başlamasıdır. Milliyetçilik akımlarının başlamasının en önemli sebebi ise Avrupa kaynaklı Hürriyet, Eşitlik, Milliyet fikirlerinin imparatorluğa girmesidir. Bu fikirler Avrupa devletlerinin kışkırtmalarıyla bütünleşince Rumların önayak olduğu ayrılık hareketleri başladı. Bu ilk teşebbüslerin Avrupa'nın desteği ile başarıya ulaşması (Mora isyanı sonucu Yunan bağımsızlığı) Osmanlı Devleti'nin varlığı için ciddi tehlikeler doğurmaya başlamıştı. İşte böyle bir durumda imparatorluğun geleceğini tehlikede gören devlet ve fikir adamları Osmanlılık diyebileceğimiz bir ideoloji geliştirdiler. Çeşitli fikri ve fiili hareketlere bir tepki olarak gelişen Osmanlılık önce fikri çerçevesi ile ortaya konulmuş ondan sonra fiili meyvelerini vermişsti. Osmanlılık ilk defa 1839 Tanzimat Fermanı ile ortaya konulmuştur. Çünkü fermanda ilk defa Müslüman olmayan halkaların da haklarından söz ediliyordu. Yani Osmanlılığın temel dayanaklarından eşitliğin sağlanmasis ${ }^{14}$ yolunda ilk adımlar Tanzimat Fermanı ile atılmıştı. Buradan anlaşılacağı üzere Osmanlılık idealinin ilk kurucuları Tanzimat'ı ortaya koyan Mustafa Reşit, Âli, Fuat ve Sadık Rıfat Paşalardı. Yani Osmanlılık ilk defa bir resmi ideoloji olarak ortaya konulmuştur. Bu devlet yöneticileri çeşitli halkların maddi taleplerine cevap vermek için nasıl maddi 1slahatlar yapmışlar ve bunları Tanzimat ve Islahat Fermanları gibi hukuki belgelerle ortaya koymuşlarsa devletin menfaati için yaptıklarına inandıkları bu gibi hareketlerin ideolojik boyutunu da geliştirmişlerdir. İşte Osmanlılık bu tür bir çabanın ürünüdür. ${ }^{15} \mathrm{Bu}$ şekilde otaya konulan Osmanlılık prensibi Tanzimat dönemi ve daha sonraki dönemlerin düşünürleri tarafindan en çok benimsenen ve üzerinde en çok tartışılan görüşlerden biri olacaktır.

13 Niyazi Berkes, Türkiye’de Çağdaşlaşma, (Ankara, Bilgi yayınları, 1973), 218.

14 Filli durumda zaten azınlıklar özellikle ekonomi, ticaret, eğitim, yargı gibi alanlarda geniş imtiyazlara sahiptiler. Yani ferman sadece bu hakların hukuken teyidi ile yeni imtiyazlar verilmesinden ibarettir.

15 Bernard Lewis, Modern Türkiye’nin Doğuşu, Çeviren: Metin Kıratlı, (Ankara, TTK yayınları, 4. Bask1, 1992), s. 55- 60. 


\subsection{Osmanlıcılık Fikrinin Savunucuları ve Onların Düşünceleri}

Burada dönemin çeşitli devlet ve fikir adamlarının ve düşüncelerine temas etmeden önce mühim noktayı hatırlamakta fayda bulunmaktadır. Bir devlet veya fikir adamı "ben bu düşüncenin savunucusuyum" diyerek sadece o düşünce akımına uygun görüşler seslendirmemiştir. Aynı kişinin değişik fikir akımlarının düşüncelerini farklı zamanlarda hatta bazen de eş zamanlı olarak ifade ettiğini görmek mümkündür. Bu noktada makalenin konusu olması itibariyle öncelikle dönemin yönetici ve düşünürlerinin Osmanlılık ideallerini ifade ettikleri eserleri, tavırları açıklanmış bununla birlikte münasebet geldikçe aynı kişinin değişik görüşlerine de atıfta bulunulmuştur.

\section{Resmî Belgelerde ve Devlet Adamlarının İfadelerinde Osmanlıcılık}

Daha önce değinildiği gibi Osmanlıcılık bir fikir akımı olarak ilk defa Tanzimatçı devlet adamları tarafından ortaya atılmıştır. Ne var ki bu tanımlama daha önceki devlet adamları ve padişahlarda Osmanlıcı fikirler olmadığı şeklinde anlaşılmamalı, belki Osmanlı Devleti'nin tebaası olmak sebebiyle aynı milletin ferdi olunması fikrinin Tanzimat ile sistemleştirdiğini ifade etmesi şeklinde düşünülmelidir. Bu çerçevede mesela II. Mahmut'un merkeziyetçiliğini de Osmanlıcılık yönünde atılmış bir adım olarak değerlendirebiliriz. Şüphesiz II. Mahmut’un bu politikayı uygularken ki amacı otoritesini güçlendirmek idi. Bir Osmanlı milleti meydana getirmek değildi. Ancak güçlenen yerel otoritelere karşı sürdürdüğü bu çalışmanın yerel otoritelerin temel dayanaklarından olan ulusal niteliklere karşı mücadeleyi de beraberinde getirdiği bir vakıadır.

II. Mahmut'un uyguladığı bu merkeziyetçilik de eşitlik gibi Tanzimatçı devlet adamlarının Osmanlılı̆̆ yerleştirmek için başvurduğu temel unsurlardand1. Nitekim Tanzimat'in en önemli hedeflerinden biri Hristiyan milletlerin kopmalarının önüne geçmek ve Osmanlı birliğini muhafaza etmekti. Yani Batıcıların Batılılaşma hedefi doğrultusunda kaleme aldıkları Tanzimat Fermanı kendilerinin karşısında yer alan Yeni Osmanlıların hararetle savunduğu Osmanlıcılık ideali doğrultusunda söylemler içermekle kalmıyor bir anlamda Onun kuruculuğunu yapıyordu. ${ }^{16}$

Tanzimat Fermanından sonra aynı doğrultuda değerlendirilebilecek Islahat Fermanı (1856) denilen bir belge daha yayınlandı. Fermanda eşitlik vurgusu yanında Osmanlılık açısından diğer bir önemli nokta da ilk defa halkın temsil edileceği meclis reformlarından söz edilmesiydi. Bu durum Fermanın Osmanlıcı niteliğinin daha belirgin olduğu şeklinde okunabilir. Ancak fermanda öngörülen reformların uygulanması Osmanlılık bilincinin uyanması sonucunu doğurmuyor, aksine çoğu zaman Osmanlıların hedeflediği birliğin tersi sonuçlar doğuruyordu. Nitekim yabancılara verilen yeni ayrıcalıklar, onların milli bilinçlerini ve dolayısıyla ayrılma isteklerini artırıyordu. Zamanla Islahat Fermanıyla amaçlanan beraberliğin aksine sonuçlar ortaya çıktığı gayrimüslimlerin Avrupa'nın da desteğiyle kendilerine sağlanan imkânları Müslüman tebaayı çok geride bırakır şekilde kullandıkları görüldü.

Bundan başka Tanzimatçı dediğimiz devlet adamlarına muhalif yöneticilerde de Osmanlıcılık fikrinin önemli bir yer tuttuğunu hatta bunların Tanzimatçı yöneticileri İslamc1- Osmanlıcı karışımı bir bakış açısıyla eleştirdiklerini görürüz. Burada şu nokta dikkat çekicidir ki, Tanzimat'a karşı ilk tepkiler Osmanlıcı olmaktan çok İslamcı bir karakter taşıyordu. Yani Müslümanlar Tanzimat’tan zarar gördüler düşüncesi ile ifade ediliyordu. Bunlara örnek olarak dönemin önemli devlet ada-

16 Fermanın amacı devleti kurtarmaktır. Batılılaşma devleti kurtarmak için bir araçtır. Yani bu devlet adamları devleti kurtarmanın yolunu Batılılaşmada gördüğü için batıcıdır. Nitekim bu amaç doğrultusunda hiç de Batılı olmayan Osmanlılık gibi düşünceleri de seslendirmiş olmaları esas amacın Batılılaşma değil devleti kurtarmak olduğunu gösterir. 
mı, tarihçi ve hukukçusu Ahmet Cevdet Paşa verilebilir. Kendisi İslam-Osmanlı temeline dayalı bir görüşü benimsemişti. İmparatorluğun her yerinde bütün tebaaya karşı uygulanacak bir kanun olan Mecellenin vücuda getirilmesi, bütün mahkemelerin kararlarını denetleyebilecek bir Adliye Nezaretinin kurulması gibi özellikle hukuk alanında yapılan birleştirici çalışmaları Osmanlıcı bir bakış açısıyla değerlendirebilir.

II. Abdülhamit (1876-1908) zamanında da özellikle yönetimin ilk yıllarında Osmanlılık prensibi kabul edilmiş ve hatta I. Meşrutiyet gibi somut uygulamalar ile uygulanmasına geçildiği halde 1880 'lerden sonra özelikle Hristiyan halkın tutumu yani ayrılık hareketlerinin devam etmesi nedeniyle Osmanlıcılığın İslamcılığın içine girerek varlığını sürdürdüğünü görüyoruz. Bu durumu II. Abdülhamit'in özellikle saltanatının ilk yıllarında hiçbir milleti gücendirmeme politikasını ön plana çıkarmışken 1880'lerden sonra gittikçe artan bir şekilde hilafet kimliğine özel önem vermeye başlamasından anlayabiliyoruz. I. Meşrutiyet döneminin önemli devlet adamı ve Meşrutiyetin ilanında önemli katkıları bulunan Mithat Paşa da imparatorluğun çöküşüne karşı bütün din ve 1rk farklılıklarını ortadan kaldıracak bir eşitlikle oluşturulmuş bir meclis teklif ediyordu. Burada görüldüğü gibi ilk defa Osmanlıcılık fikirleri resmi bir ağızdan Meşrutiyetle özdeşleştirilerek ortaya konuluyordu. ${ }^{17}$

II. Abdülhamit'ten sonra tahta geçen V. Mehmet Reşat da Osmanlıcı bir düşünceyle hareket etti. Yayınladığı ilk fermanda halkın din ve ırk ayrımı gözetilmeksizin Osmanlı olarak hür ve eşit olacağını, vatanı, devleti ve milleti için çalışacağını belirtiyordu. Burada vatan Osmanlı vatanı, millet Osmanlı milleti, devlet de Osmanlı Devleti idi. Bunlar Osmanlıcıların oluşturmak ve topluma uyarlamak istediği yeni kavramlard.

\section{Dönemin Aydınlarında Osmanlıcılık Fikri}

Osmanlılık fikri ilk defa devlet adamları tarafından ortaya atılmıştı. Ancak onu asıl sahiplenen ve sistemleştirip bir ideoloji haline getiren dönemin aydınları olmuştur. Bunların başında Osmanlıcılık fikrinin asıl kurucuları diyebileceğimiz Yeni Osmanlılar geliyordu. 1865'te kurulan Yeni Osmanlılar cemiyetinin programını hareketin önde gelenlerinden Namık Kemal bir yazısında "şu anki idare sebebiyle devletin içine düştüğü zorlukları görüp ona çare aramak" şeklinde tarif ediyordu. Yani onların da asıl amacı devleti kurtarmaktı. Cemiyetin üyelerinden Ebuzziya Tevfik bunu Osmanlı halkını din ve ırk ayırmaksızın özgürlük içinde tek vücut halinde birleştirmektir şeklinde açıkladı. Diğer taraftan Yeni Osmanlılar, Osmanlıcılık düşüncesini şer’i delillerle kuvvetlendirerek Müslüman halka benimsetmek için çalıştılar. ${ }^{18}$

Devleti kurtarma hedefinin gerçeklemesi için milletin birliğini sağlamanın gerekli olduğuna inanmışlar, bu sebeple de Osmanlıcılık idealini benimsemişlerdi. Yaptıkları çalışmalarla Osmanlılık ideolojik bir anlam kazandı ve kendileri tarafından vatan sınırları içinde birçok milletlerden meydana gelen imparatorluğun bütün halklarının eşitliği ve birliği şeklinde tanımlandı. Burada kastedilen vatan ise var olması hedeflenen Osmanlı vatanı idi. Onlara göre bu düşüncenin gerçekleşmesi için hukukta eşitlik ve menfaatte birlik sağlanmalı idi. ${ }^{19} \mathrm{Bu}$ birliğin sağlanması için ise parlamento vazgeçilmezdi. Cemiyetin kuruluş amacı da aslında bu doğrultuda memlekette mutlakıyet rejimine son vererek meşruti bir yönetim kurmaktı. Böylece her millet eşit olarak temsil edilip parlamentosu

17 Şerif Mardin, Jön Türklerin Siyasi Fikirleri (1895-1908), (İstanbul, İletişim Yayınları, 1989), s. 60.

18 Demir, 342.

19 Tülin Ürenay, II. Abdülhamit Devrinde Fikir Hareketleri (1876-1908), Hacettepe Üniversitesi Sosyal Bilimler Enstitüsü, Yüksek Lisans Tezi, Ankara, 1975, s. 23-24. 
aracılığıyla yönetimine katıldığı devlete sahip çıkacaktı. Bu amaçlarını gerçekleştirmek için 1867 yılında harekete geçmeye karar verdiler. İlk fiili icraatları Mehmet Emin Âli Paşa’yı sadrazamlıktan indirip yerine Mahmut Nedim Paşa'yı sadarete getirmeye çalışmak oldu. Ancak teşebbüsleri akim kaldı. Kendileri için imparatorlukta tutuklamalar ve sürgünler dönemi başladı. Bunun üzerine cemiyetin bazı üyeleri Paris’teki Mustafa Fazıl Paşa'nın² daveti üzerine Avrupa'ya kaçtılar ve faaliyete geçtiler.

Yeni Osmanlılar Avrupa'da bir yandan hürriyet ve meşrutiyet hedefleri doğrultusunda basın yoluyla çalışmalar sürdürüyorlardı. Ne var ki diğer kendi aralarında Osmanlılık politikalarını başarısızlığa uğratacak davranışlarda bulundular. Birbirlerine karşı müthiş bir rekabet ve karalama kampanyası yürüttüler ve İslamcılık Türkçülük gibi çeşitli fikirlere yönelmeye başladılar. ${ }^{21} \mathrm{Bu}$ dönemde Mustafa Fazıl Paşa'nın Abdülaziz'in Avrupa seyahatinde kendini affettirip İstanbul'a dönmesi de maddi imkânlarını yok etti. Bu durum aralarında yeni ayrılıklar gündeme getirdi. Çeşitli mücadelelerden sonra hareket dağıldı ve üyeleri hükûmetle anlaşıp İstanbul'a döndüler. Yeni Osmanlılar basın yoluyla faaliyetlerini İstanbul'a döndükten sonra da sürdürdüler. Önde gelen şahsiyetleri Namık Kemal, Ziya Paşa, Ali Suavi ve Şinasi idi. Bunlar sorunlara farklı tarzlarda yaklaşıyor, ayrı metotlar öneriyorlardı. Ortak noktaları ise devleti kurtarmak hedefleri, Osmanlılık idealleri ve çözümlerinin meşrutiyette düğümlenmesiydi. Mesela Namık Kemal yazılarında başlıca üç temel sorun tespit etmiş ve onlara şöyle çözümler öneriyordu:

Devletin çöküş nedeni siyasal ve ekonomik sebeplerdir.

Bu süreci tersine çevirmenin yolu eğitimdir.

Bunun için gerekli reformların en önemlisi anayasal meşruti bir temele dayalı merkeziyetçi bir devlet rejimidir. ${ }^{22}$

Görüldüğ̈̈ gibi burada Osmanlılık idealinin hayata geçirilmesinin en önemli iki aracı meşrutiyet ve merkeziyetçilik kavramları vurgulanmıştır. Anayasal meşruti yönetim fikri ona göre Osmanlılık ideolojisinin hayata geçirilmesinin en önemli aşamalarındandır. $\mathrm{Bu}$ fikrin temelinde bir hedef alarak ulaşılmasını istediği Avrupa medeniyetinin özgürlük, eşitlik ve meşrutiyete dayandığı inancı vardır. Onun Osmanlılık fikrinin temeli Müslümanların beraberliği ve Hristiyanlarla uzlaşmadır. Bu çerçeveden bakıldığında Onun İslamcı-Osmanlıcı bir fikir yapısına sahip olduğu düşünülebilir.

Namık Kemal Tanzimat'ın getirdiği Batılılaşmaya karşı ilk defa milliyetçilik bilinci uyandırmaya çalışan kişidir. Ancak Onun milliyetçiliği, doğumunu hedeflediği Osmanlı Milliyetçiliğidir. Namık Kemal'e göre hukukta ve menfaatte birlik sağlanabilirse dil, din, 1rk farklılıkları yeni bir milletin oluşturulmasına engel değildir. Bu ideolojinin yerleşmesi için her milletin çocuğunun aynı okullarda Osmanlılık idealleri doğrultusunda yetişmesi gereğini savunmuştur. Namık Kemal bu önemli adımların atılmasıyla Osmanlı birliğinin gerçekleşeceğine ve Avrupa'dan da yeni medeniyetin alınmasıyla eski güzel günlerin geleceğine inanmaktadır. Yani ona göre Avrupalıların Avrupa medeniyeti ile İslam’ın birleştirilemeyeceği fikri yanlıştır. Osmanlı Devleti Osmanlılığından

20 Mustafa Fazıl Paşa Mısır tahtının meşru varisi idi. Veraset kanununda yapılan bir değişiklikle bu hakk1 elinden alımınca mücadelesini önce İstanbul'da daha sonra da Avrupa'da sürdürmeye başlamıştı. Meşrutiyetin ilanı Osmanlılık birliğinin sağlanması gibi emeller beslememekle birlikte mücadelesinde destek olabilecekleri inancıyla Yeni Osmanlılara yardım etmişti. Mücadelesi tamamen şahsi idi.

21 Mardin, 31-33.

22 Namık Kemal, "Şark Meselesi”, Makâlât-ı Siyâsiyye ve Edebiyye, Mabaa-i Ebuzziya, İstanbul, 1328, s. $1-2$. 
vazgeçmeden medeni bir devlet olabilir. Yani O, ilim ve teknikte Batıcılık, kültür ve değerlerde Osmanlıcılık, inançta İslamcılık taraftarıdır. ${ }^{23}$

Yeni Osmanlıların önde gelen temsilcilerinden olan Şinasi laikliğin ve milliyetçiliğin öncüsü kabul edilir. Ali Suavi ise medreseden yetişmiş bir şahsiyettir. Bu özelliğinin de etkisiyle İslamcı yönü ağır basmaktadır. Ancak O da Namık Kemal gibi Osmanlı Devleti'nin Batı'nın maddi gücünü elde etmesi gerektiği taraftarıydı.

Dönemin diğer önemli şahsiyetlerinden hem devlet adamı hem de fikir adamı kimliği ile ön plana çıkan Ahmet Mithat Efendi de "Yeni bir Osmanlı milleti var. Osmanlılık bir siyasi bağlılık olarak padişahın tebaası olmayı kabul etmekten ibarettir" diye Osmanlıcı düşüncelerini ortaya koyuyordu. ${ }^{24}$

Yeni Osmanlıların muhalefet hareketi siyasal anlamda İstanbul'a dönmelerinden sonra, basın yoluyla yaptıkları muhalefet ise 1880 'lerden sonra son bulmakla beraber fikirlerinin tamamen son bulduğu söylenemez.

Kendilerinden sonra da hemen hemen aynı gayelerle kurulan Jön Türkler muhalefet hareketinde de hem programları ve hedefleri hem kadroları olarak yer aldılar. Jön Türklerin de gayeleri devleti kurtarmaktı. Bu amaçla Osmanlı birliğinin sağlanması idealine büyük önem vermişlerdir. Hatta II. Abdülhamit 1880'lerden itibaren Osmanlılık politikasının başarısızlığı ile İslamcılığa doğru yönelirken Jön Türkler 1910'lara kadar Osmanlılık idealini yaşatmaya çalışmışlardır.

Yeni Osmanlılardaki hizipleşme Jön Türklere de aktarılmıştır hatta aralarındaki görüş ayrılıkları daha da belirgindir. Mesela Yeni Osmanlıların hepsi devleti kurtarmak idealine matuf Osmanlıcılığ tır. Aralarındaki ayrılıklar ise kabul ettikleri Osmanlılık idealine nasıl ulaşılacağından hatta Osmanlıcılık idealine ulaşmak için ortak olarak temel araç gördükleri meşrutiyet rejiminin nasıl hayata geçirileceğinden ibarettir. Bu noktada Ziya Paşa'nın önderlik ettiği propaganda yolunun seçilmesinden tutunuz da Ali Suavi'nin önderlik ettiği ihtilal teşebbüslerine varıncaya kadar geniş bir yelpazede düşün ve hareket sahasında idiler. Ancak Jön Türkler de amaçta ve araçta da farklılıklar mevcuttur. Bu durumda Jön Türkler arasında ortak nokta sadece devleti kurtarmaktır denilebilir. $\mathrm{Bu}$ hedefe ulaşmak için farklı ideolojiler ve bu ideolojilerin uygulanması için farklı metotlar geliştirmişılerdir. Gerçi hareketin ilk ortaya çıktığı dönemlerde hemen hemen hepsi Osmanlıcı idiler. Bu ideal doğrultunda metot geliştirmeye uğraştılarsa da özellikle İttihat ve Terakki adlı grubun iktidara gelmesinden sonra Osmanlı birliğini kurmanın mümkün olmadığının anlaşılmasıyla resmi olmasa da düşün sahasında çeşitli ideolojilere yönelmişlerdir. Böylece diyebiliriz ki Yeni Osmanlılarda tartışılan sadece nasıl sorunu ise (nasıl meşrutiyeti ilan edebiliriz) Jön Türker'de bunun yanında neden (neden meşruti yönetim, neden merkeziyetçi veya adem-i merkeziyetçi devlet yapısı) ve niçin (niçin Osmanlılık, Türkçülük veya İslamcılık) sorunları da tartışılmıştır. ${ }^{25}$

Yeni Osmanlılarla Jön Türkler arasında bundan başka farklılıklar da vardı. Mesela Yeni Osmanlılar Avrupa'daki düşünce hareketlerinden fazla etkilenmemişken Jön Türkler daha fazla etkilenmişlerdir. Bu farklılıkları dolayısıyla Jön Türkler başlıca iki gruba ayrıldılar: Bunlar İttihat ve Terakki Cemiyeti’nin temsil ettiği Ahmet Rıza grubu ile Teşebbüs-ü Şahsi ve Adem-i Merkeziyet

23 Niyazi Berkes, Batıcılık, Ulusçuluk ve Toplumsal Devrimler, (İstanbul, Yön Yayınları, 1965), 60.

24 Berkes, s. 60-66; Mardin, s. 35. 
Cemiyeti etrafında örgütlenen Prens Sebahattin grubu idi. Bunlardan başka bu gruplardan bağımsız olarak Abdullah Cevdet ve Mizancı Murat gibi şahsi hareket eden veya etraflarında kendilerine inanmış küçük gruplar bulunan Jön Türkler de vardı. Bu grupların hepsi üyelerinin düşünce farklılıklarından doğmamıştı. Aralarındaki şahsi anlaşılmazlıklar nedeniyle ayrı çalışan fakat aynı amaç doğrultusunda faaliyet gösteren gruplar da vardı. Her ne maksatla olursa olsun her biri Batılı fikirlerin ayrı bir yönünün Osmanlı Devleti'ne taşıyıcısı olmuşlardır. Ancak burada şunu unutmamak gerekir ki Osmanlılar Batılı fikirleri her zaman bir seçme yaparak algılamışlar Batı'nın bazı yönlerini vurgulayıp bazı yönlerini arka plana itmişlerdir. ${ }^{26} \mathrm{Bu}$ grupları ve savundukları fikirleri dikkatle incelersek bu durumu oldukça net bir şekilde görebiliriz. Mesela Ahmet Rıza baskı yönetiminin kaldırması gereği üzerinde 1srarla durmasına rağmen anayasal bir rejimden yana değildir. Baskı rejiminin kalkmasını ise meşrutiyet yönetiminde görüyordu. 1889'da Askeri Tıbbiye de kurulan İttihat ve Terakki Cemiyeti onun görüşlerini benimsemişti. Zaten kendisi de zamanla cemiyetin önderi konumuna yükselecektir. İttihat ve Terakki mücadelesini Avrupa'da sürdürdü. Cemiyet, iktidara geldikten sonra içinde değişik ideolojiler savunan hizipler oluşmuşsa da Osmanlı Devleti'nin sonuna kadar en azından resmi söylem olarak Osmanlılık ideolojisini benimsemişti. Özellikle Avrupa'da sürdürülen mücadeleler dönemine rastlayan Ahmet Rıza'nın liderliği yıllarında bu ideal tavizsiz bir şekilde savunulmuştu. Ancak Osmanlılığın tesisi konusunda izlenecek yol bu dönemde de ihtilaflıdır. Hatta cemiyet içinde kurucuların her birinin ayrı dinden olması fikri istekleri, hedefledikleri Osmanlı birliğinin simgesi olarak düşünülmüştür. Bu idealleri doğrultusunda kuvvetli merkezi bir otoritenin bulunması gerektiğini de söylüyorlardı.

İttihat ve Terakki Cemiyeti adından da anlaşılabileceği gibi birleşme ve ilerlemeyi esas tutmakta idi. Bu amaçlarına ulaşmak için kendisi gibi rejim aleyhindeki bütün gruplarla birleşme çalışmaları yapmış, kısmen de başarılı olmuştur. İttihat ve Terakki Meşrutiyet'ten sonra iktidarı gittikçe ele almaya başlamış. 1913'ten sonra da idareye tamamen hâkim olmuştur. Ancak idareyi ele aldıktan sonra diktatörlüğe yönelmiştir. Bu dönemdeki liderleri ise 1905-6'dan sonra Dr. Nazım ve Bahattin Şakir Beyler, iktidarın tamamen ele alınmasından sonra ise bunun gerçeklemesinde en büyük pay sahibi olan Rumeli askerlerinin önde gelen İttihatçı subayları Enver, Cemal ve Talat Paşalardır. Dr. Nazım ve Bahaddin Şakir'in liderliği döneminde azınlıklara karşı kırgınlık ve güvensizlikle karışık bir iyi geçinme siyaseti takip etmişler, fakat bundan kendileri de pek memnun olmamışlardır. Bu dönemde gayrimüslim unsurları da Osmanlılık idealinin tesisine çalışmak şartıyla cemiyete kabul edebileceklerini, bu hedef doğrultusunda çalışan herkes milliyetine bakmadan Osmanlı kabul ettiklerini belirtmişlerdir. ${ }^{27}$ Bunun yanında bilhassa yurtdışındaki Müslümanlarla temaslarında İslam vurgusuna dikkat etmişlerdir. Fakat özellikle Balkan savaşlarından sonra Osmanlılığın gerçeklemesinin imkânsızlığı anlaşılınca resmi söylemde değilse de fiiliyatta farklı politikalara yönelmişlerdir. İttihat ve Terakki bundan sonra takip ettiği politikalara bakılarak milliyetçilerin cemiyeti olarak adlandırılmıştır.

Jön Türklerin diğer önemli şahsiyetlerinden Mizancı Murat ${ }^{28}$ ise Osmanlılık birliği altında özellikle devlet tipinde İslamcılığa yönelik fikirler ortaya koymuş, bunun yanı sıra Türklüğe de kıymet vermeye çalışmıştır. Ona göre Osmanlı vatandaşlarının eşitliğini sağlayan bir meşruti yönetim sayesinde Türkçe yaygınlaşacak, bu da Osmanlılık bilincinin gelişmesinin kültürel temeli olacaktır. Kısaca Mizancı Murat’ta Osmanlılık, İslamlık ve Türkçülük ideallerinin birbiri içine

26 Burada millet kavramının din bağlamında değerlendirilmesi o dönemde milletin belirlenmesinde dine atfedilen önemin göstergesidir. Mardin, Türk Modernleşmesi, s. 17; Tarık Zafer Tunaya, Türkiye'nin Siyasi Gelişme Seyri içinde ikinci Jön Türk Harekelerinin Fikri Esasları, (İstanbul, 1986), 20.

27 Yusuf Hikmet Bayur, Türk Inkılabı Tarihi, (Ankara, TTK yayınları, 4. Bask1, 1992), c. 1, s. 372-376.

28 Asıl ismi Mehmet Murat'tır. (1854-1917) Mizan diye bir dergi yayımladığı için bu adla anılmaktadır. 
girdiğini söyleyebiliriz. Ancak burada yine de Türkçe dilinde dil birliğinin Osmanlıcılık idealine hizmet etmesi düşüncesiyle seslendirildiğini göz önüne alırsak Onda yine de Osmanlılık idealinin temel olduğu ifade edilebilir. Ayrıca Osmanlılık birliği emeli doğrultusunda ayinlerinin Türkçe yapılacağı -ki burada Türkçeye vurgusu var amaç sadece birliktelik değil- bir Osmanlı millî kilisesi kurulmasını öneriyordu. Ne var ki önerisi bizzat kendi çalıştığı gazetenin yöneticileri tarafından kimsenin dinine ve kavmiyetine karışmamak gerektiği düşüncesiyle hoş karş1lanmıyordu. ${ }^{29}$

İttihat ve Terakki cemiyetinin kurucularından olan ancak cemiyetin Ahmet Rıza gurubunun eline geçmesiyle cemiyetten uzaklaşan Abdullah Cevdet'te de Osmanlı vatanperverliği içine yerleştirilmiş bir Türklük duygusu vardı. Bu duygu onda gittikçe kuvvet bulmuş ve Abdullah Cevdet 1905 y1lında Osmanlı Milleti tabirine bile itiraz etmeye başlamıştır.

Jön Türklerin diğer bir önemli temsilcisi Prens Sabahattin ise meşrutiyete dayalı Osmanlılık taraftarıydı. Ona göre bütün Osmanlı halkları bir Osmanlı milleti meydana getiriyorlardı. Ancak milletler bunun bilincinde değillerdir. Bu bilincin sağlanması için hangi milletten olduklarına bakılmaksızın tüm Osmanlı unsurlarına iyi bir eğitim verilmeliydi. Önderi olduğu Teşebbüsü Şahsi ve Adem-i Merkeziyet Cemiyeti çeşitli milletlere özerklik verilmesi taraftarıydı. Ancak Osmanlı Devleti'nin federal bir yapıda olmasıyla, Osmanlı birliğinin sağlanabileceğini savunuyordu. Bu düşünceden hareketle bölgelerinde özerklik isteyen milli grupları desteklemekte bir sakınca görmüyordu. Nitekim bu düşünceleri nedeniyle diğer Jön Türkler tarafından ihanetle suçlanmıştır. Bununla beraber Prens Sebahattin de Osmanlı birliğini bozacak bağımsızlık hareketlerine karşıydı. Prens Sabahattin, Osmanlı Devleti'nde hürriyetin yerleşmesi için gerekirse Avrupa müdahalesini bile hoş karşılıyordu. İttihat ve Terakki grubu ise bağımsızlıklarını zedeleyecek böyle bir harekete şiddetle karşıyd1. ${ }^{30}$ Aslında Jön Türklerin en önemli özlemi hürriyet değil Osmanlı Devleti'nin parçalanmasını durdurmaktı. Hürriyet ise bu noktada kendileri için bir araçtı. ${ }^{31}$

\section{Osmanlıcılık İdealinin Fiili Uygulamaları}

Bir resmî ideoloji olarak ortaya konulan ve dönemin pek çok önemli fikir adamı tarafından da benimsenen Osmanlılık idealinin hem resmi çevrelerin hem de fikir adamlarının ortaya koyduğu birçok somut uygulamasıyla karşılaşıyoruz. Bunları şu başlıklar altında tasnif ederek ifade edebiliriz:

\section{1. İdari Alanda Osmanlıcılık}

İdari alanda Osmanlı birliği fikrinin uygulamalarına ilk defa Tanzimatçı devlet adamlarının öncülüğünde ortaya çıkan Eyalet Meclislerinde rastlıyoruz. Bu meclislerde bütün Osmanlı tebaası Tanzimatçıların Osmanlılık idealinin temel aracı eşitlik ilkesi doğrultusunda temsil edilmiştir.

Osmanlıcığın idari alanda uygulanışının bir diğer göstergesi de Tanzimatçıların önderliğinde uygulamaya konulan ve yine dayanak noktası eşitlik olan gayrimüslimlerin de devlet hizmetinde üst görevlere kabulüdür. Mesela Sultan Abdülaziz tarafından Şurâ-î Devlet Üyeliğine atanan isimlerin bir kısmı gayrimüslimlerden idi. Bu konuda Kanun-i Esasi'nin 19. Maddesi açık hüküm içermektedir. Ad1 geçen madde “Devlet me'muriyetinde umûm tebaa ehliyet ve kabiliyetlerine göre münâsib

\footnotetext{
29 Mardin, Jön Türklerin Siyasi Fikirleri, 118.

30 Stanford Show ve Ezel Kural Show, Osmanlı Imparatorluğu ve Modern Türkiye, Çev. Mehmet HARMANCI, (İstanbul, e yayınları, 1983), c. 2, s.314.

31 Mardin, Jön Türklerin Siyasi Fikirleri, s. 219-220.
} 
olan me'mûriyetlere kabûl olunurlar" şeklinde ifadesini bulmuştur. ${ }^{32}$ Anlaşılan Osmanlıcılığın en önemli somut uygulanması diyebileceğimiz hem eşitliğe hem de meşrutiyete dayalı bir uygulama I. Meşrutiyet'tir. Bilindiği gibi meşrutiyet Yeni Osmanlıların en temel isteği idi. Onun için ve Anayasasının hazırlanma aşamasında Yeni Osmanlılar cemiyetinin Namık Kemal gibi bazı üyelerinin de görev alması cemiyetin faaliyetlerinin en önemli sonucuydu. Gerçi Meşrutiyetin ilanı sadece Yeni Osmanlıların gayretlerinin neticesi olmamış, iç ve dış birçok etkinin -Mesela Batıcıların da isteği yani onlar eşitlik olmadığı iddiasıyla Avrupa’nın yaptığı baskının önüne geçmek için meşrutiyeti bir araç görmüşlerdir- yanı sıra bizzat Padişah II. Abdülhamit'in de Meşrutiyetin Osmanlı birliğine vasıta olabileceğini düşünmesi muhtemeldir. Çünkü biz II. Abdülhamit' in özellikle saltanatının ilk yıllarında Osmanlılık idealine daha çok önem verdiğini biliyoruz. Bu durumda meclisin istenilen gayeye ulaşmaya yetmediğini anlamasıyla da meclisi kapatmış olmaktadır. Ancak meclis kapatmasını da sadece böyle bir nedene dayamak güçtür. Abdülhamit'in Meclisi kapatmasından sonra da muhalif hareketler meşrutiyete bağlılıklarını sürdürmüşler, çeşitli mücadelelerden sonra meşrutiyeti 1908 yılında yeniden ilan ettirmeye muvaffak olmuşlardır. II. Meşrutiyet Dönemi, hürriyet ortamının da tesiriyle, devletin yıkılışını engellemeye yönelik çözüm arayışlarının zirveye ulaştığı bir dönem olmuştur. Ayrıca bu dönemde basın-yayın üzerindeki denetim ve sansürün ortadan kalkması, Osmanlı entelektüel hayatına da ivme kazandırmıştır. ${ }^{33}$ Peyami Safa Türk İnkılâbına Bakışlar adlı eserinde, II. Meşrutiyet'in ilânı ile ortaya çıkan bu ortamı; "dolgunluğu, taşkınlığl, zenginliği ve coşkunluğuyla bu, çok canlı bir fikir ve iddia panayırıdır" ş̧eklinde tanımlamıştır. ${ }^{34}$

\subsubsection{Hukuki Alanda Osmanlıcılık}

Tanzimat Fermanı'nda “Osmanlıcılık ve Osmanlı Vatanperverliği” düşüncesi temel bir hedef olarak yer almakta idi. Fakat fermanın bir taraftan şer-i şeriften söz ederken diğer yandan gayrimüslimlerin eşitliğinden söz etmesi, etnik yapının hukukî statüsünü belirlemede sıkıntı doğurdu. Fermanın ilk kez Müslüman veya gayrimüslim tüm uyrukların aynı haklara ve yükümlülüklere sahip olacaklarını ilan etmesi Osmanlı Devleti'nde o zamana kadar görülmemiş bir tanımlama idi. Anlaşılan Ferman Müslümanlar ile gayrimüslimler arasında eşitliği sağlayarak yakınlaşmayı amaçlıyordu. O zamana kadar sadece bir hanedan ismi olan "Osmanlı" Ferman ile artık yukarıdan aşağıya doğru farklı etnik kimlikleri kaynaştıracak bağ olarak kullanılıyor, farklı bir anlam kazanıyordu. Aynı şekilde Islahat Fermanı'nın gayrimüslimlere yönelik hükümlerine bakıldığı zaman da gayrimüslimlerin hak ve sorumluluk bakımından Müslümanlarla eşit statüye taşınmak istendiği görülmekteydi. ${ }^{35}$

Devlet adamları tarafından da hukuk alanında Osmanlı birliğini sağlamaya yönelik eşitlik temeline dayalı bazı düzenlemeler yapılmıştır. Mesela Islahat Fermanı'yla Hristiyanların da silah taşımalarına izin verileceğinin ve askere kabul edileceğinin ilanı -bu eşitlik ilkesine dayalı olduğu görünse de orduya yeni insan gücü bulmak amacını da güdüyordu ve Hristiyanları hiç de memnun etmemişti- ve cizyenin kaldırılması -askerlik yerine isteyen Hristiyanların bedel verebileceğinin getirilmesi de cizye işlevini görmüştür ki zaten cizye de askere gidebilecek olanlardan alınan baş vergisidir- bu alanda atılmış adımlardır. Hukuki alanda bu adımların çok daha önemlisi bütün

\footnotetext{
32 Düstur, 6.

33 Fuat UÇAR, "Türk Düşüncesinde Osmanlıcılık Fikrinin Ortaya Çıkışı ve Türk Siyasal Hayatına Etkileri”, Karadeniz Sosyal Bilimler Dergisi, c. 10, s. 18, s. 84.

34 Peyami Safa, Türk İnkılâbına Bakışlar, (4. Basım, İstanbul, Ötüken Neşriyat, 1999), s.11.

35 Demir, 337-340.
} 
tebaayı yargılama yetkisine sahip ${ }^{36}$ özellikle ticari alanda yeni mahkemelerin kurulması ve bütün mahkemelerin bir üst mercii olan bir kurulun oluşturulması idi. Eşitlik ilkesine dayalı bir diğer düzenleme ise bu kurulun üyelerinin her dinden insanlardan oluşmasıydı.

Tanzimat döneminde hazırlanan ceza kanunu da bu yönüyle değerlendirilebilir. Gerçekten 14 Temmuz 1851'de yeniden düzenlenen Ceza Kanunnamesi sınıf, mezhep ve din farkı gözetmeksizin bütün Osmanlılara uygulanmak üzere yürürlüğe girmişti ve en temel özelliği eşitlikçi bir bakış açısıyla kaleme alınmış olmasıydı. Ayrıca bu kanun dünyevileşmenin ilk adımları diyebileceğimiz düzenlemeler de içeriyordu. Daha sonra çok önemli bir hukuki düzenleme olan Mecelle ile karşılaşıyoruz. Ahmet Cevdet Paşa tarafindan hazırlanan bu kanun şer-i kanunlar ile Avrupa kanunlarını bir manada uzlaştırmak amacını güdüyordu ki ilk defa Avrupa kanunlarının somut tezahürleri bu kanunlarda görülmüştür.

Bir Osmanlı milletini Osmanlı vatanında yaşıyor olmak ortak kimliği üzerinden meydana getirmek amaçlı çalışmalar daha sonra da devam etti. Ortak vatan etrafinda birleşmeyi esas alan Abdülaziz, 19 Ocak 1869'da dokuz maddeden oluşan Tâbiiyet-î Osmaniye Kanunnamesini kabul etti. Kanunun temel özelliği, Müslüman ve Hıristiyan ayırımı yapılmaksızın bütün halkı kapsamasıdır. Kanun, dini anlayışa dayalı vatandaşlık mefhumunu terk ederek onun yerine Batı hukukundaki uyrukluk kavramını yerleştirmekteydi. ${ }^{37}$

Bütün bu çalışmaların en ileri noktası olarak Osmanlı tebaasının hukuki olarak eşit olduğunu ifade eden en somut kayıt ise herhalde yukarıda "Eşit Haklara Dayalı Osmanlılık" bahsinde geçen Osmanlıların memleketin hukuk ve vazifelerinde eşit oldukları şeklindeki Kanun-i Esasi hükmü olduğu tanımlanabilir. ${ }^{38}$

\section{Eğitim Alanında Osmanlıcılık}

Eğitim alanında da birliği sağlama amacına yönelik ve eşitlik temeline dayalı düzelmemeler yapıldı. Bu alandaki ilk düzenlemeler II. Mahmut zamanında başlamıştı. Onun döneminde açılan eğitim kurumlarına bütün Osmanlı tebaalarının kabul edileceği bildirildi. Burada dünyevileşme ve batılılaşmanın da etkisi olduğu gibi milletin eşit ve bir kabul edilmesinin de etkisi olduğu anlaşılmaktadır. Zaten fikir adamlarının ifade ettiği düşünceleri sadece bir akımın çerçevesi içine değerlendirilmemesi gerektiği gibi devletin attığ görülmemelidir. Aslında hedef noktasında belki bir birlik her fikirde ve her uygulamada vardı. $\mathrm{O}$ da ifade edildiği gibi devleti içine düştüğü durumdan kurtarmaktı. Ancak bu nihai hedefe varmak için yollar da araçlar da her zaman çeşitlilik göstermiştir.

Tanzimat döneminde hazırlanan Maarif Nizamnamesinin de Osmanlıcı bir yönü vardı. Buna göre ilköğretim her din ve mezhepten halkın çocukları için Türkçe olarak düzenleniyordu. Böylece birleştirici millet politikası için vazgeçilmez bir unsur olan dil birliği sağlanmaya en azından tüm tebaanın ortak bir dili biliyor olması sağlanmaya çalış1lıyordu. Rüştiyeden sora ise herkes kendi dilinde eğitim yapacaktı. Daha sonra Yükseköğretimde de Osmanlıcı düzenlemeler yapıldı. Avrupa'ya öğrenci gönderme yerine açılan bir Mektebi Sultanide her milletten gençlerin hem batılı

36 Daha önce gayrimüslimlere hukuki alanda özerklik verilmiş kendi aralarındaki hukuki işleri cemaatlerinin oluşturacağı dini mahkemelerine, Müslümanların işleriyse şer 'iye mahkemelerine bırakılmıştı.

37 Demir, 341.

38 Kanun-i Esasi ile sonrasında yapılan tüm hukuki düzenlemelerin tam metinleri ve değerlendirilmesi için bk. Cemal GÜVEN, Anayasalar, Kanunlar ve TBMM Kararları (1876-2016), (Eğitim Yayınları, Konya, 2016). 
bilimlerle donatılması hem de birer Osmanlı aydını olarak yetiştirilmesine çalışıldı. Daha sonra bu sultaniler imparatorluğun diğer büyük vilayetlerine de yayıldı. Bu okullarda Osmanlılık idealine aykırı olacağı ve yabancı ögrencileri incitebileceği gerekçesiyle Türk Kültürüne yer verilmezken okulların fiili olarak azınlıkların milliyetçilik duygularının gelişmesine katkıda bulunduğu görülmüştür.

\section{Dil ve Edebiyatta Osmanlıcılık}

Osmanlı Devleti'nde resmi dil Osmanlıca idi. ${ }^{39}$ Osmanlıcanın da temeli Türkçe olmakla birlikte imparatorluğun bütün halklarının katkılarıyla şekillenmişti. Ancak bu dil sadece yönetici elite mahsus kalmıştı. Halk Türkçesi ise zaten hem Türk halkı hem de azınlıklar arasında da konuşulmaktaydı. Ancak azınlıklar kendilerinde milli bilinç uyanmasıyla birlikte kendi dillerine daha fazla ilgi göstermeye başlamışlardı. Bu durum birçok bölgede doğrudan Türkçe’ye veya Osmanlıcaya karşı değil kiliseye karşı bir hareket olarak ortaya çıkıyordu. Dönemin Osmanlıcı aydınları da edebi eserlerinde kozmopolit bir dil olarak değerlendirdiği Osmanlıcaya daha fazla önem vermişlerdir. Mesela Servet-i Fünûn Edebiyatında ağır bir Osmanlıcanın kullanılması bu yönüyle de değerlendirilebilir. Bu donemde bütün halka hitap eden kahramanların aynı milletten insanlar olduğu yani Osmanlı milletinden olduklarının anlatıldığı eserler de ortaya konulmuştur.

\subsection{Osmanlılık İdealinin Sonu}

\subsubsection{Sağladığı Kısmi Başarı}

Osmanlıcılık ideolojisi sonuçta başarısız olmuş yani hedefi olan devleti kurtarmak emeline ulaşamamışsa da hem vatan millet, meşrutiyet, eşitlik hürriyet gibi kavramların imparatorluğa gelişine sebep olmuş hem de bazı sınırlı başarılar elde etmiştir. Buna II. Abdülhamit' in tahta gelişinden sonra onu tahttan indirip tekrar V. Murat'1 getirmek isteyenlerin oluşturduğu Skalyeri-Aziz Bey komitesi örnek verilebilir. Çünkü çeşitli dinlerden insanların üye oldukları komite ilk toplatısında milletin selameti için çalışacaklarını dile getirmişti. Demek ki komite üyeleri için millet kavramının anlamı eski Osmanlı literatüründe var olan dini anlamdaki millet kavramından farklı olmalıydı. Gerçi komite üyelerini bir araya getiren aynı milletten oldukları inancından çok menfaat birliği idi. Ancak yine de komitenin ideolojik temeli ortaya konulurken Osmanlıcıların oluşturmak istedikleri anlamda millet tabirinin kullanılması toplumun böyle bir şeyi kabullenmeye çok da yabancı olmadı̆̆ını gösterir. ${ }^{40}$

Bundan başka Osmanlı Devleti’nde görevli bazı gayrimüslim yöneticilerinde kendilerini Osmanlı olarak gördüğü etnik kimliklerini fazla ön plana çıkarmadıkları görülmüştür. Buna en iyi örnek ise Osmanlı Devleti’nin bir dönem Yunanistan elçisinin bir Rum olmasıdır.

\subsubsection{Nihai Başarısızlık ve Tepki Olarak Gelişen İdeolojiler}

Osmanlı devletinin birliğinin ve bekasının tehlikeye düştüğü bir zamanda Osmanlı Devleti'nin çeşitli yöneticileri temelde devleti kurtarmak amacına yönelik bir Osmanlı birliği oluşturmaya yö-

\footnotetext{
39 Osmanlıca mı yoksa Osmanlı Türkçesi denmesi gerektiği tartışmalıdır. Konu dilbilimcilerin sahasında olduğundan bu tartışmaya değinilmemiştir. Ancak ifadenin makalenin konusu açısından önemi vardır ki metinde temas edilmektedir. Lewis, s. 175-178.
} 
nelmiş̧lerdir. Ancak Osmanlılık çalışmalarının istenen neticeyi vermemesi ayrılık hareketlerinin devam etmesi devlet adamlarını ve düşünürleri devleti kurtarmaya yönelik başka ideolojiler aramaya yöneltti. Bu görüşler Osmanlıcılığın zararına gitgide İslamcılığa ve Türkçülüğe yöneliyordu. Nihayetinde Osmanlıcı devlet adamlarının ve aydınların hedefi devleti kurtarmaktı ve Osmanlıcılık bu hedefe giden yolda sadece bir araçtı. Bu aracın istenilen hedefe ulaştıramayacağının görülmesi diğer taraftan hedefe ulaşmanın yani devleti kurtarmanın aciliyet kesbetmesi bu yönde çabaları artırd1.

Bu noktada Osmanlıcılığın gerilemesiyle bir yandan Batıcılık gibi farklı zeminlerde gelişen fikir akımlarının ötesinde Osmanlıcılık ile istediği başarıyı elde edemeyen ancak gayesi tabii ki Osmanlıcılık değil devleti kurtarmak olan dönemin fikir ve devlet adamlarının Osmanlıcılık temelleri üzerine bina ettiği fikirlere temas etmenin yararları vardır. Ancak öncesinde Osmanlıcılık idealine neden ulaşılamadığının değerlendirilmesi yerinde olur ki bu değerlendirme Osmanlıcılığın aksayan yönleri ve yerine ikame edilen ideolojiler ile hangi açıkların kapatılmaya çalışıldığını da ortaya koyabilmemize yardımcı olabilir.

Osmanlıcılığın istenen hedefe ulaşamayışının yani araçta yeni bir Osmanlı milleti meydana getirilmesine imkân oluşturamayışının, hedefte ise Osmanlı Devleti'ni kurtaramayışının sebeplerinin en önemlisi Osmanlılık bilincinin oluşturulması için vazgeçilmez unsurlardan biri olan bir Osmanlı kültürünün oluşturulmasının imkânsızlığı idi. Çünkü bir Osmanlı kültürü meydana getirmek için vazgeçilmez bir şart olan bir Osmanlı dili yoktu. Her ne kadar Osmanlıca çeşitli dillerin katkıları ile oluşturulmuş bir dil olsa da temeli Türkçe idi ve o zamanki gayrimüslim halk onu Türkçe kabul ediyordu. Bu durumda bir Osmanlı kültürü oluşturulması için kullanılacak dil zorunlu olarak Türkçe olacaktı. ${ }^{41}$ Böylece Osmanlı birliği oluşturma hareketi daha başlangıçta bir milletin lehine yapılmış bir hareket şeklini alıyor ve mantığını kaybediyordu. ${ }^{42}$

Aslında burada Osmanlıcılık birleştiricilik özelliğini değil eşitlikçi temelini kaybediyordu. Ancak Osmanlıcılık fikrinin banisi Yeni Osmanlılar için en önemli unsur eşitlik değil birliktelik idi. Bu hedefin hayata geçirilmesi için eşitlikten ödün verebiliyorlardı. Bu sebeple gayrimüslimler Osmanlılık birliğinin tesisi için yapılan bazı düzenlemelerden memnun olarak, bu düzenlemelerin sonucu olarak kabul edildikleri değişik konumlarda devlete hizmet etseler de millî kimliklerini gururla taşıdıkları için bağımsızlık özlemlerinden vazgeçmemişler, yeni bir milleti oluşturacak bir kaynaşmanın gerçekleşmesine firsat tanımamışlardır. Bunda gayrimüslimlerin Osmanlıyı Türk ile özdeş görmesi ve Osmanlılaştırma çabalarını bir Türkleştirme hareketi olarak değerlendirmesinin de etkisi büyüktür. Diğer taraftan Osmanlı Devleti'nin Anadolu ve Ortadoğu'daki Müslüman halkı da buna hazırlıklı değildi. Daha da ötesi bu siyaset Avrupa devletlerinin de işine gelmiyordu. Eşitliğe ve kaynaşmaya yönelik çabalarda, Avrupa devletlerinin her firsatta yaptıkları müdahaleler de başka bir engel oluşturuyordu. ${ }^{43}$

Osmanlıcığın başarısızlığının bir nedeni de o dönemde dünyada hâkim olan milliyetçi politikaların tersine bir yaklaşım içermesi idi. Sonuçta Müslümanlarla gayrimüslimleri kaynaştıracak eşitlik prensibini uygulama, aynı vatan etrafında birleştirme süreci, zamanla hızını yitirdi ve

41 Bu zorunluluğu içeriğinde bir Osmanlı milleti oluşturulması hedefine yönelik birçok kayıt bulduğumuz Kanun-i Esasi de açıkça görüyoruz. Nitekim 18. Madde: "Tebaa-i Osmâniyye’nin hidemât-ı Devletde istihdâm olunmak için Devlet'in lisan-ı resmîsi olan Türkçe'yi bilmeleri şartdır" derken 57. Madde "Hey'etlerin müzarekâtı lisan-ı Türkî üzere cereyan eder ve müzâkere olunacak lâylhaların sûretleri tab' ile yevm-i müzakereden evvel a'zâya tevzî̀' olunur" demektedir. Düstur, 6-11.

42 Mardin, Jön Türklerin Siyasi Fikirleri, s. 192.

43 Demir, 343. 
Osmanlıcılık ideolojisi Balkan savaşlarında Osmanlı Devleti'nin yenilgisiyle son buldu.

$\mathrm{Bu}$ tarihten sonra Osmanlıcı aydınlar bu fikrin ulaşılması mümkün olamayan bir hedef olduğunu değerlendirirek temel amaçları olan devleti kurtarmak yolunda farklı görüşleri savunmaya başladılar. Bunların en önemlileri ise İslamcılık ve Türkçülük idi. Hakikaten aynı aydının bir dönem Osmanlıcı olmasına rağmen daha sonra İslamcı ya da Türkçü görüşler serdetmesi sık karşılaşılan bir tutumdur ve kronolojik olarak bakıldığında sıklıkla ilk önce Osmanlıcı daha sonra İslamcı ya da Türkçü olduğunu görmek mümkündür.

\section{İslamcilık}

Hareket 1840'lardan beri Müslümanca bir tepki olarak ortaya konuluyordu. Tanzimat'a gösterilen tepkide de Osmanlıcılık değil İslamcılık hâkimdi. Fikirlerinin odak noktası Tanzimat'la birlikte Osmanlıların kendi benliklerini kaybetmeye başladıkları idi. Daha sonra hem Osmanlıcılık ideolojisinin başarısızlığa uğrayacağının anlaşılmasıyla hem de imparatorluk içinde daha az gayrimüslim kalmasıyla geliştirilecek birleştirici ideolojilerde gayrimüslimlerin nazara alınmayabileceği fikri doğdu. Müslüman milletleri imparatorluğa bağlı tutmak ise onlara Osmanlılıktan daha çok hitap eden ideolojilerle daha kolay mümkün olabilirdi. Bütün Müslüman tebaaya hitap edebilecek ve tabii ki Osmanlıcılıktan çok daha fazla toplumsal dayanağı olan İslam'dı. Ayrıca onlara göre Müslüman tebaanın bağlılığı ile devlet güçlenirse gayrimüslim tebaa da devlete zorla bağlı tutulabilirdi. ${ }^{44} \mathrm{Bu}$ açıdan bakıldığında İslamcılığın birçok yönüyle mesela devleti kurtarma amacına yönelik olması noktasından -ki bu zaten temel amaçtı- Osmanlıcılıktan doğduğu söylenebilir. Nitekim bundan sonra Osmanlıcılık, İslamcılık içinde varlığını sürdürecektir. İslamcı tepki Müslümanların Rusya'da ve yeni ayrılan Balkan devletlerinde gördükleri davranışın da etkisiyle kuvvet buldu. Namık Kemal ve diğer Yeni Osmanlılar İslam'1 vurgulamakta II. Abdülhamit'ten önce davrandılar. II. Abdülhamit de Müslüman tebaası arasında zaten yaygın olan bu fikri hem iç hem de dış düşmanlara karşı güçlenmek için kullandı. Böylece Panislamizm resmi politika oldu. İslamcılık ile yakın olmakla yani aynı kaynaktan beslenmekte birlikte daha farklı bir fikir akımı olan ya da kısa bir ifadeyle İslamcılığın özellikle dış politikaya bakan yüzü olan Panislamizm politikası ile II Abdülhamit imparatorluk içinde Müslümanlara seslenerek batıcıları ve milliyetçileri bastırmada güç kazanıyor, dış dünyada ise önemli bir Müslüman kamuoyu desteği sağlıyordu. II. Abdülhamit'in bu politikası bir süre başarılı oldu. Buna örnek olarak 1897 Osmanl1-Yunan savaşının bütün İslam âleminde bir Müslüman-Hristiyan çatışması telakki edilerek Osmanlı Devleti'nin zaferi ile sevinilmesi verilebilir.

İslamcılık II. Abdülhamit'ten sonra da Jön Türkler tarafından da içte ve dışta kullanılmış ve aralarında ciddi taraftarlarda bulunmuştur. Özellikle ilk dönemlerde Osmanlıcılığa ağırlık veren Jön Türklerin çoğu zamanla İslamcılığa yönelmişlerdir. Yani İslamcı ideoloji tabanının önemli kısmımı Osmanlıcılardan sağlamıştır. Yalnız Hilafet meselesi bundan hariçtir. Hilafetin devamı istisnasız bütün Jön Türkler tarafından savunulmuştur.

\subsubsection{Türkçülük}

Osmanlı İmparatorluğu'nun kurucusu olan Türker'de milli bir şuur uyanması diğer milletlerden oldukça geç oldu. Çünkü onlar Osmanlı milletini öylesine benimsemişlerdi ki kendi mil-

44 Ercüment Kuran, "XIX yy'da Türkiye'de Kültür Değişmesi”, ERDEM, C. 6 S. 16, (Ankara, 1992), s. $220-222$. 
li özelliklerini onun içinde eritmişlerdi. Bu sebepten Türklerin ortaya koyduğu düşünceler önce Osmanlıcık sonra da İslamcılık gibi birleştirici ideolojilerdi. Ancak zamanla bu ideolojiler sadece Türklerin savunduğu birer ideal haline geldiler. Bu durum bazı Türk aydınlarında Avrupa ile temas etmelerinin de etkiyle Türklük duygusunun kuvvetlenmesine yol açtı. İlk ortaya konulan şekliyle Türkçülük bir Kültür Türkçülüğü idi. Dilde Türkçecilik olarak seslendiriliyordu. Türkçülere göre Türkler imparatorluğun kurucuları olması dolayısıyla ayrı bir önemi haizdi. Bu fikirler tabi öncelikle Osmanlılık ideali ile karşı karşıya geldi. Ancak Türkçülük fikrinin ilk ortaya koyulduğu dönemde Türkçüler 1srarla Türkçülük fikirlerinin Osmanlılığın gelişmesine engel olmayacağını savunmuşlardı. Hatta onlara göre Türklerin kuvvetlenmesi Osmanlı birliğini kuvvetlendirecekti. Çünkü onlar Osmanlılık çerçevesi içinde kendi milli duygularını yaşatmaya çalışıyorlardı ve imparatorluğun asıl sahipleri oldukları içinde böyle bir şeyi yapmaya da hakları vardı. II. Abdülhamit'in de Batıcılara karşı kullanmak amacıyla zaman zaman bazı Türkçü faaliyetleri himaye ettiği biliniyorsa da ideolojiye asıl destek Jön Türker'den geldi. Jön Türkler arasında zamanla daha fazla Türklere önem verildi. Nihayetinde İttihat ve Terakki Cemiyeti gittikçe daha fazla Türkçülüğe yöneldi.

Bu fikrin Osmanlı Devleti'ne taşınmasında yurt dışına gönderilen öğrencilerin de tesiri büyüktür. Ancak asıl Türk milliyetçiliğinin kurucusu Ziya Gökalp'tir. O, çeşitli fikir akımlarını tahlil ettiği ve sonunda Türk milliyetçiliğini en uygun bulduğu Türkleşmek, İslamlaşmak, Muasırlaşmak adlı eserinde Tanzimatçı Türklerden başka kimse için bir anlam ifade etmeyen Osmanlı milleti kavramını devlet ve milletler için sadece faydasız değil özellikle Türkler açısından oldukça zararlı bulur. Çünkü asır milliyetçilik asrıdır ve Osmanlı Devleti'ni meydana getiren milletleri bir arada tutmak mümkün değildir. Bunun için bir an önce çağdaş İslam Türklüğü oluşturulmalıdır. ${ }^{45}$

Türkçülük idealinin o dönemdeki en önemli savunucularından biri de Yusuf Akçura'dır. Çeşitli Jön Türk dergilerine yazdığı makalelerinde dönemin önemli fikir akımlarını değerlendirir. Mesela Ona göre Osmanlılık Osmanlı tebaasının devlete borçlu olduğu bir siyasal bağımlılıktır. Bundan başka bir Osmanlı milleti yoktur ve çalışmakta boşunadır. Çünkü özellikle imparatorluk içindeki gayrimüslim unsurlardan sert tepki görür. Panislamik politika da devlet içinde fazla bir engelle karşılaşmasa da dış dünyada Hristiyan uluslardan sert tepki görür ve başarısızlığa uğrar. İşte bu noktada O Türkçülüğe yönelir yani Türk ırkına dayanan bir Türk milli yapılanmasını önerir. Ona göre böyle bir politika imparatorluk içindeki Türk ırkının bağlılığını pekiştirdiği gibi Osmanlı sınırları ötesinde de Türklerin bağımlılığını da kuvvetlendirecek en ideal yoldur. ${ }^{46}$

Fikir olarak geç telaffuz edildiği gibi uygulama olarak da Türkçülük idealinin tahakkukuna yönelik adımlar geç atıldı. Bu konudaki somut çalışmaların İttihat ve Terakki Partisi’nin Osmanlı Devleti'nin yönetimine ağırlı̆̆ını koyduğu yıllarda başladığı ve I. Dünya Savaşı yılları boyunca sürdürüldüğü kabul edilir. İttihat ve Terakki'nin önderlerinden Talat Bey dönemin ileri gelen siyaset yapımcıları arasında yer aldı. Dolayısıyla cemiyetin Türkçülük politikalarının tespiti ve uygulamasında mühim rol üstlendi. ${ }^{47}$ Aynı şekilde İttihatçı liderlerden Cemal Paşa I. Dünya savaşında Suriye' de ordu komutanı iken Arap milliyetçi liderlere karşı sert tedbirler aldı. Mesela 21 Ağustos 1915 'te kendi komuta ettiği bölgede on bir Arap milliyetçi lideri oluşturulan askeri mahkeme kararı ile idam edildi. I. Dünya savaşından sonra ise bu faaliyetleri neticesinde Osmanlı devletindeki

45 Ziya Gökalp, Türkleşmek, İslamlaşmak, Muasırlaşmak, (İstanbul, Toker Yayınları, 2. Baskı, 1992), s. 9-15.

46 Yusuf Akçura, “Türkçülük”, Türk Yılı, I, 1928, s. 396.

47 Ayrıntı için bk. Şükrü HANIOĞLU, “Talat Paşa”, İslam Ansiklopedisi, (c. 39, Türkiye Diyanet Vakfı Yayınları, İstanbul 2010), s. 502-503. 
Arap unsurunun isyanına sebep olmakla itham edildi ve gıyabında idama mahkum edildi. ${ }^{48}$ Hatta çağdaşları tarafından Cemal Paşa'nın Osmanlı Devleti'nin Orta Asya'daki toprakları üzerinde bağımsız bir Türk devleti kuracağı ve kendisinin de bu devletin hükümdarı olmayı planladığı da iddia edilmiştir. Çarlık Rusya'sı Hazine Nazırı Sazanov bunlardan biridir. Ne var ki bu iddialara ihtiyatla yaklaşmakta fayda vardır. Nihayetinde Sazanov Osmanlı Devleti ile savaşta olan Rusya'nın bir yetkilisidir ve pekala kendi hükümetini Osmanlı Devleti'nin bir yöneticisi aleyhine harekete geçirmeye teşvik sadedinde bu şekilde beyanatta bulunmuş olması muhtemeldir. ${ }^{49}$ Her ne sebeple olursa olsun Osmanlı Devleti'nin bir yöneticisi için Türkçülük ideali doğrultusunda hareket etmiş olduğunun telaffuz edilmesi bu düşüncenin mâkes bulmuş olduğunu göstermesi açısından kayda değerdir.

Ancak Türkçülük ideali doğrultusunda yapılan asıl çalışmaların Osmanlı devlet adamları tarafından değil yeni kurulan Türkiye Cumhuriyeti yöneticileri eliyle uygulama sahasına geçtiği müşahede edilecektir.

\section{Sonuç}

Osmanlı Devleti kurulduğundan beri toplum yapısını İslam dinini referans alarak düzenlemişti. Buna göre Müslümanlar ya da "milleti hâkime" tek millet olarak değerlendiriliyor iken, "milleti mahkûme" yani gayrimüslimler din hatta mezheplerine göre ayrı ayrı milletler olarak teşkilatlanmışlardı. Mesela bütün Hristiyanlar ya da aynı din içindeki mezhep boyutunda bakarsak tüm Ortodokslar bir millet olarak değil Rum Ortodoksları, Ermeni Ortodoksları, Bulgar Ortodokslar şeklinde ayrı milletler olarak mütalaa edilmekteydi. Aynı durum Ermeniler için de geçerliydi. Ortodoks Ermenileri ayrı Katolik Ermenileri ayrı olarak değerlendirilmekte idi. Bahsi geçen milletler ayrı kiliseler çatısı altında teşkilatlanmış bulunmaktaydı. İdari açıdan kendisi için kolaylık sağlayan bu düzeni Osmanlı Devleti güçlü olduğu, tüm düşmanları ile tek başına başa çıtığı uzun yüzyıllar boyunca herhangi bir sıkıntı yaşamadan sürdürdü.

Ancak zaman içinde Osmanlı Devleti’nin zayıflaması düşmanlarına Fransız ihtilalinin yaydığg hürriyet, eşitlik, milliyetçilik düşüncelerini Osmanlı Devleti içindeki azınlıklar üzerinde kendi hedefleri doğrultusunda yayma imkânı verdi. Gün geçtikçe zayıflayan Osmanlı Devleti'ne kabul ettirdikleri anlaşmalarla devletin gayrimüslim tebaasına daha fazla haklar vermesini hatta onların koruyucusunun kendileri olmasını sağladılar.

Zamanla milli duyguları uyanan ve bu uyanışta Batılı devletlerin de katkısıyla kendi yollarına gitme talepleri atan Millet-i Mahkûme'nin bu taleplerinden vazgeçmesi kendisini imparatorluğa bağlı hissetmesi için Osmanlı devlet ve fikir adamlarının bulduğu çözüm ise bir Osmanlı milleti inşa etmek idi. Kısaca aynı devletin tebaası olma temelinde aynı milletin fertleri olunduğu düşüncesinin uyandırılması olarak tanımlanan Osmanlıcılık anlaşılacağı gibi ortak bir tarih, din, ırk, hedef birliği gibi milleti oluşturan temellerden yoksun olarak tamamen ihtiyaçtan doğmuş devleti kurtarmak için var olan probleme üretilmiş palyatif bir çözüm idi ve tam da bu dayanaklardan mahrum olduğu için başarılı olamadı.

48 Şükrü HANİĞLUU, “Cemal Paşa”, İslam Ansiklopedisi, (c. 7, TDV. Yayınları, İstanbul 1993), s. 307.

49 Mesela Nevzat ARTUÇ Tarih Dergisi’ndeki makalesinde "Cemal Paşa’nın Aliye'deki idamlar dolayısıyla Arap ayrılıkçı hareketlerinin başlıca sorumlusu olduğu, Suriye'de müstakil bir Sultanlık kurma çabası içerisinde bulunduğu ve Mısır Fatihi olma arzusuyla yanıp tutuştuğu şeklinde tarihi gerçeklerle bağdaşmayan iddialar ilk defa tarafımızca kullanılan belgelerin ve diğer şahitliklerin muhakemesi yardımıyla çürütülmüştür” demektedir. Nevzat ARTUÇ “Cemal Paşa’nın Suriye Valiliği 1914-1917” Başlıklı Doktora Tezi Üzerine Mühim Bir Değerlendirme” Tarih Dergisi, (S. 67, İstanbul, 2018), s. 178. 
Osmanlılık düşüncesinin banileri tasavvur ettikleri yeni milleti inşa etmek için Avrupa'dan gelen modern düşünceler diye tanımlayabileceğimiz gerçekten Osmanlı Devleti'nin ve toplumunun ihtiyaçlarından doğmamış olan ve devlet ve toplumda çok da karşılığı bulunmayan eşitlik gibi fikirlerden ve meşrutiyet gibi rejimlerden yararlanmak istediler. Ancak bu amaçla yaptıkları düzenlemeler gayrimüslimleri memnun etse de hedeflendiği gibi onların kendilerini Müslümanlarla aynı milletten hissetmelerine yetmedi. Hatta oluşturulan fikir ortamları ayrılma duygularını, imkânlar ise Avrupalı dostlarından da gördükleri teşviklerin de katkısıyla ayrılma cesaretlerini besledi. Kısaca daha çok hürriyet, eşitlik hatta yönetime katılım onları daha çok Osmanlı yapmadı. Daha kolay yollarına gitmelerine imkân sağladı. Çünkü yüzyıllarca Osmanlı tebaasında yaşamış olmalarına rağmen milli benliklerini korumuşlardı. Yüzyıllarca ayrılma isteklerinin olamayışı ayrılacak gücü bulamamış olmalarından kaynaklanıyordu ve bu imkânı bulduklarında da Osmanlı Devleti'ne itaat etmeyi bırakma iradesine yöneldiler. Osmanlı Devleti'nin son zamanlarında ortaya atılan bu Osmanlıcılık fikri, herhangi bir tarihi temele dayanmayan sadece günü kurtarma amaçlı seslendirilen bu yeni millet inşa etme çabaları başarısız olmuş, farklı milletlere siz aynı devletin vatandaşısınız öyleyse aynı millettensiniz demenin bir karşılığı olmamıştı. Zaten olmayan bir Osmanlı milleti var etme düşüncesinin başarısızlığını gören Osmanlı devlet adamları ve aydınları da daha fazla ortak noktaların olduğu Müslümanların tek millet olduğu ve sonunda da İslam milletlerinde de ayrılık düşüncelerinin gelişmesiyle Türklerin birliği hedeflerine yöneldiler.

\section{Kaynakça}

Ahmet Cevdet Paşa, Tarih-i Cevdet, Cilt: 1, Üçdal Neşriyat, İstanbul, 1994.

Akçura, Yusuf, Üç Tarz-ı Siyaset, Ankara, Türk Tarih Kurumu Yayınları, 1976.

Akçura, Yusuf, “Türkçülük”, Türk Yılı, Sayı: 1, 1928.

Artuç, Nevzat, “Cemal Paşa’nın Suriye Valiliği 1914-1917” Başlıklı Doktora Tezi Üzerine Mühim Bir Değerlendirme” Tarih Dergisi, S. 67, İstanbul 2018, s. 177-192

Bayur, Yusuf Hikmet, Türk Inkılabı Tarihi, c. 1, 4. Baskı, Ankara, TTK Yayınları, 1992

Berkes, Niyazi, Batıcılık, Ulusçuluk ve Toplumsal Devrimler, İstanbul, Yön Yayınları, 1965. , Türkiye’de Çăgdaşlaşma, Ankara, Bilgi Yayınları, 1973.

Demir, Şerif, "Tanzimat Döneminde Bir Devlet Politikası Olarak Osmanlıcılık”, Selçuk Üniversitesi Türkiyat Araştırmaları Dergisi, S. 29, 2011, s. 331-348. 1992.

Gökalp, Ziya, Türkleşmek, İslamlaşmak, Muasırlaşmak, 2. Baskı, İstanbul, Toker Yayınları,

Güven, Cemal, Anayasalar, Kanunlar ve TBMM Kararları (1876-2016), Eğitim Yayınları, Konya, 2016.

Hanioğlu, Şükrü, “Cemal Paşa”, İslam Ansiklopedisi, c. 7, TDV. Yayınları, İstanbul 1993, s. 305-307. , “Talat Paşa", $\dot{I} A$, c. 39, TDV yayınları, İstanbul 2010, s. 502-503.

İğdemir, Uluğ, Kuleli Vakası Hakkında Bir Araştırma, TTK Yayınları, Ankara, 2009.

Karal, Enver Ziya, Osmanlı Tarihi, 4. Baskı, c. 7. Ankara, TTK Yayınları, 1973.

Kuran, Ercüment, “XIX yy.'da Türkiye de Kültür Değişmesi”, ERDEM, c. 6, S. 16, Ankara, 
1992.

Lewis, Bernard, Modern Türkiye'nin Doğuşu, 4. Baskı, Çeviren: Metin Kıratlı, TTK. Yayınları, Ankara, 1992.

Mardin, Şerif, Jön Türklerin Siyasi Fikirleri (1895-1908) İstanbul, İletişim Yayınları, 1989. , Türk Modernleşmesi, 4. Baskı, İstanbul, İletişim Yayınları, 1994.

Namık Kemal, "Şark Meselesi”, Makâlât-ı Siyâsiyye ve Edebiyye, Mabaa-i Ebuzziya, İstanbul, 1328.

Ortaylı, İlber, Imparatorluğun En Uzun Yüzyılı, İstanbul, Hil Yayınları, 1983.

Özcan, Azmi, “Osmanlıc1lık”, Diyanet İslam Ansiklopedisi, c. 33, TDV. Yayınları, 2007, s. 485-487.

Safa, Peyami, Türk Inkılâbına Bakışlar, 4. Basım, İstanbul, Ötüken Neşriyat,1999.

Show, Stanford ve Ezel Kural Show, Osmanlı Imparatorluğu ve Modern Türkiye, c. 2, Çeviren: Mehmet Harmancı, İstanbul, e Yayınları, 1983.

Tunaya, Tarık Zafer, Türkiye’nin Siyasi Gelişme Seyri içinde ikinci Jön Türk Harekelerinin Fikri Esasları, İstanbul, 1986.

Uçar, Fuat, “Türk Düşüncesinde Osmanlıcılık Fikrinin Ortaya Çıkışı ve Türk Siyasal Hayatına Etkileri”, Karadeniz Sosyal Bilimler Dergisi, c. 10, S. 18.

Ülken, HilmiZiya, “Tanzimat'tan Sonra Fikir Hareketleri” 100. Yılında Tanzimat Sempozyumu 1939, Maarif Vakfı Yayınları, Ankara, 1940.

Ürenay, Tülin, II. Abdülhamit Devrinde Fikir Hareketleri (1876-1908), Hacettepe Üniversitesi Sosyal Bilimler Enstitüsü, Yüksek Lisans Tezi, Ankara, 1975. 